Vol. 31 (2021) 1-8 | e-ISSN: 2213-056X

Note from the $L Q$ editor: There is already a great deal written about the impact of COVID-19 on libraries and their future services. Elisabeth Bergenäs and Lotti Dorthé are librarians at the Malmö University in Sweden. In spring 2021, they ran some staff focus groups to explore stories about the impact of COVID-19 on the people who work in the library. Here, through our first $L Q$ guest editorial on our new journal platform, they share what they discovered as restrictions begin to lift across Europe.

\title{
Why the Simple Act of Listening will Help us Design Strong and Sustainable Post Pandemic Library Services
}

\section{Elisabeth Bergenäs}

Malmö University Library, Sweden

elisabeth.bergenas@mau.se

\section{Lotti Dorthé}

Malmö University Library, Sweden

lotti.dorthe@mau.se, orcid.org/0000-0001-7001-7236

Keywords: COVID19; library services; future library; digital services.

\section{When the Pandemic Hit}

March 11 2020, the World Health Organization stated that the virus outbreak is a pandemic. Unlike other European countries, Sweden did not introduce any official lockdown but provided guidelines and restrictions for the society where universities moved their services and courses online. At Malmö 
University the Vice-Chancellor, Kerstin Tham, decided on March 152020 that the university would move teaching and examining from on site to digital. Malmö University closed all the university premises but one. The Orkanen building, where the main library is situated, remained open so that researchers and students had access to $\mathrm{Wi}-\mathrm{Fi}$, computers and literature. It was decided to keep the functions at one library site up and running during the pandemic but to switch to digital channels to a large extent. In three days the staff and the functions at the library were reorganised completely. The learning environment in the Orkanen library was still accessible. Half the number of chairs were removed, the group rooms were closed and a maximum number of visitors was set. A new plan for the library developed. Most of the librarians worked at the physical library one day a week. The library was still open at regular hours for students and staff, but for the first six months the service desks were unstaffed. After summer 2020, librarians were back to help the visitors on site but referred to the digital channels as much as possible. At this time the public users could return to the library again.

Stricter measures were presented at the government's press conference in December 2020. One of these was a recommendation to immediately close all state, regional and municipal activities (including libraries) that were "not absolutely necessary" until January 24 2021. This led to a debate in Swedish society and among librarians (Eriksson, 2020). Karin Linder, Secretary General of the Swedish Library Association opposed. "In general, it is wrong to mention libraries in the same sentence as swimming pools and sports halls. Libraries are ultimately an activity that guarantees free speech and everyone's equal right to information" (quote, author's translation). Education had been identified by the government as a primary function for society during the pandemic so, while many (mostly public) libraries in Sweden closed immediately, some remained open.

\section{The Focus Groups}

We became interested in how the pandemic affected the librarian's dayto-day work and decided to examine our colleagues' experiences during this period. We ran two focus groups in April 2021 with 12 librarians who were selected to represent various competencies and areas of work. We 
encouraged an open discussion to get an overview of how the pandemic changed the routines for our colleagues and the services for our users. We asked two questions:

1. In what way have your work tasks and your work situation changed during the COVID-19 pandemic?

2. What have you learned from the experiences and what do you want to develop after the pandemic?

Three strong themes emerged: the digital shift, remote working and the library as place.

\section{The Digital Shift}

The pandemic reinforced and accelerated already ongoing trends in library investments in digital resources and services (Frederick \& Wolff-Eisenberg, 2020). Librarians taught, tutored and performed services online instead of at the library. At Malmö University, the librarians in the focus groups were positive about working remotely. A teaching librarian said, "We meet the students in another way. Now they are in my living room instead of in a lecture room. My experience is that they are attending the sessions in another way than before." At first, there was a period of learning to use the techniques and tools but now the librarians felt that they could handle the new formats and started to think about the pedagogical possibilities. A librarian who works with search consultations said that she felt that the tension that some students feel when they go to the library for a search consultation has disappeared when meeting online: "There are elements in physical tutoring that can affect learning, many steps for the student before the actual meeting starts, and maybe meeting online can have an anti-anxiety effect?"

It was found that new researchers participated more frequently in digital workshops. Some of them we would probably not have reached on site. A librarian working with research support said, "Tutoring is easier online. For example, when it comes to reference management, it is an advantage to be able to share a screen. And researchers have found their way to us, better and faster than before. They don't have to book a meeting and leave their own desk." The digital shift was also an improvement for the librarians who work with the library systems, "I can do the same thing at home as at the library. Some things have even 
become easier when I work with implementing systems, for example the whole access part. Before, I would have implemented it and then I would have to go home to test it. Now I see directly how it looks."

Like other academic libraries, Malmö University Library has expanded the digital resources for the past decades, and we were well prepared when it came to access but there are disciplinary differences in availability of online resources. One librarian pointed out, "We already had off campus access and both researchers and students were used to working from home. The problem was the handling of our printed material." Most of the academic literature in Swedish is not accessible online because of restrictions from Swedish publishers. It became even more important to make our e-resources visible online in a readable way during the pandemic. We promoted e-resources in different channels, for example in the university's learning platform and in our LibGuides. Surprisingly, the national libraries statistics analysis showed a reduced use of licensed e-media. We suspect this is due to the increase in the amount of open digital content (temporarily opened up by publishers) during the pandemic, which means that use of the resources were not always registered by libraries.

The library has been offering help to users via online chat since 2006. In March 2020, the chat became the library's primary communication channel and we saw a huge increase in demand and were able to get instant feedback from users during the covid 19-pandemic. For many librarians this was almost the only user contact they had during the Spring of 2020. The more informal communication in the chat gave a feeling of "togetherness" in the midst of things happening in the covid crisis. One librarian described the difference between a physical meeting in the service desk and the digital chat, "The tone in the chat is different. Nobody at the service desk says -thank you, that was a good help. In the chat you get a lot of smileys and flashing stars."

When the smaller branch libraries at Malmö University closed during the spring of 2020, we wanted to be more available to the students in other ways and established a digital reference desk via Zoom. We gave medicine and odontology students access to a "Digidesk" during a period when we knew that many students would need to find information for their degree projects. The concept of being available "just in time" when the students have a need of search help was a crucial factor in this service and this digital solution seemed to lower the thresholds to the library. 


\section{Remote Working}

How can we combine the benefits with working remotely and on site (Garcia Walton, 2021)? On questions about work environment, feelings in the focus groups were mixed.

"Normally I meet a lot of students and teachers every day. What I am experiencing now, at home, is that I really get a break when I have a break. Working on site there is so much chattering and so many people. Nevertheless, I miss the energy this brings. I laugh less now. I guess it is a sign that you feel good at work and have less fun now... it is nicer now, calmer but a bit more boring." There were observations about possibilities for a better work life balance, "Now when we can see that it actually works, to work from home, don't you think that this should mean that we get more freedom to work more remotely? I think generally that we perform better when having the choice. Maybe you do not have to commute to and from work every day? Maybe you do not need to work fewer hours because you want pick a kid up from football practice? You can just add an hour later."

All the librarians in the focus groups missed their colleagues and some of them had lost work motivation, "Working alone has reduced the desire to work. I do not have much inspiration. I do not feel the same creativity and job satisfaction as when I am at the library. However, I have finished many things that I have been working on for a long time. Due to the circumstances, I have got things done".

This feeling of productivity was emphasized by another librarian, "I have experienced a very deep concentration that I have not had for years. At work, you are always interested in what is happening around you, and suddenly someone knocks on the door even though you have closed it.... then you lose your focus. I think that the non-disturbance is a big advantage of working at home. I do not think I will get that feeling of concentration again if we go back as it was before."

Several of the librarians in the focus groups described losing knowledge and understanding about what other colleagues in the organisation were doing. They missed all the small talk in corridors, at coffee- and lunch breaks, "I have lost a lot of contact. Now the distance to the other department is much longer. If I want to know something, who shall I ask? How do I contact people? Sometimes I don't even try because the distance is too far." One librarian said, "I have lost the sense of belonging. Zoom meetings can be good but I appreciate meeting colleagues in real life. We usually had improvised meetings because we sit close to each other. Now we have a chat in Teams but it is not the same." 
The casual conversations are not easy to transfer from the ordinary working day at the physical library to the digital working environment. Librarians didn't think that digital meetings with the only purpose of socializing was a particularly good idea, "It's important to have a focus for the meeting, this tentative talk...you can't produce small talk out of nothing".

The remote work during the pandemic changed the social and physical work environment drastically (Barone Gibbs et al., 2021). The librarians had less in-person interactions, more screen time, some of them felt unmotivated and their experiences about belonging raises questions. What happens to the quality of the services that the library offers when the librarians are working from home and lose face to face contact with the users? What does remote work do to the quality of life and work? How can librarians create a sense of belonging for library users when they are working remotely and maybe have lost the sense of belonging themselves?

\section{The Library as Place}

Orkanen Library has been staffed $10 \mathrm{am}-8 \mathrm{pm}$ since fall 2020. This has been primarily to provide services deemed as critical, like Wi-Fi and study space (Olsen, 2019). There is of course a fine line between availability and risk of spreading the virus. One librarian in the group said, "The day you go to work on site it is great fun. I feel happy when I enter the library. What a fantastic workplace we have! How nice it must be from the students' perspective. To sit there and work. This is not a new discovery, to me, but it is very obvious right now." The bridging distance to the users is a central theme in the discussions. "I am one of those who have been working from home all the time, since I normally commute by train to work. I miss meeting the students, they make me understand what I am doing and why." Librarians felt that the sense of belonging to the workplace or feeling of being connected to the library is harder to achieve in a digital way. At Malmö University Library we normally have a student art gallery, a gallery where current research is exhibited and several annual events. During the pandemic we ran four digital book clubs to create a possibility for the students to meet online and we had a digital art exhibition.

It was also an emotional struggle for the staff when the library user service and circulation so drastically had to change. "Everything that has to do with 
circulation. Managing loans and fines has been extremely complicated during the pandemic. We had to make a lot of urgent decisions and implement solutions that no one liked. Not even those who came up with the solutions. But it was the best we could do." The library needed to change routines to follow the recommendations and at the same time there was a call to respond to the users' needs. Some of the decisions were not taken by the library, as they were in the hands of the University management. Closing access to the library for external visitors when most of the public libraries struggled to keep their services running was one of those decisions that was hard to deal with. This is a question of democracy and enabling an open dialogue between science and society (Wilson et al., 2019). The compromise was to let the public access the library during a few hours on weekdays.

\section{Moving Forward from here}

Focus group attendees had thoughts about what next:

"We will take the good experiences of digital meetings with us. I hope that we will keep in mind that there are benefits with working from home, when it is best suited for one's life situation and the work."

"I think it is important to maintain flexibility, and I think it is good to use words such as life situation because this is a part of us and how we work. If we can adapt our work situation to our life situation, it will probably benefit both the employer and our colleagues. Within a common framework of course."

"This may be the next challenge to find the common framework, when we return."

Some things are better suited for online delivery, for example short meetings, different forms of teaching, tutoring and workshops with researchers. The librarians in the focus groups could concentrate better and work effectively from home and reached new audiences for teaching sessions and workshops. They felt more free and in charge of their time.

The pandemic has created a reality of remote working and learning in higher education. In designing the future library we need to capitalise on the gains 
as well as address the potential issues, including loneliness, isolation and motivation. Sara Kjellberg, Library Director at Malmö University expressed her own thoughts,

"The digital is here to stay but the physical place and face to face meetings are also necessary, and longed for. We will learn which format to use for the best outcome and how to create a fun and engaging library on the way."

Listening to the subtle and multilayered experiences of staff can help guide the way to a sustainable and exciting future. The library is an open space, in many senses. Our physical presence there is still needed. It is necessary to meet in person, both formally and informally because it creates a culture and a mutual understanding. This culture reflects on our work environment, in the library and online. It creates a sense of belonging, which seems like an essential ingredient to preserve our welcoming and inclusive attitude.

\section{References}

Barone Gibbs, B., Kline, C. E., Huber, K. A., Paley, J. L., \& Perera, S. (2021). Covid-19 shelter-at-home and work, lifestyle and well-being in desk workers. Occupational Medicine, 71(2), 86-94. https://doi.org/10.1093/occmed/kqab011.

Eriksson, T. (2020, December 18). Fel att nämna bibliotek i samma mening som badhus. Biblioteksbladet. https://www.biblioteksbladet.se/nyheter/ fel-att-namna-bibliotek-i-samma-mening-som-badhus/.

Frederick, J. K., \& Wolff-Eisenberg, C. (2020, December 9). Academic library strategy and budgeting during the COVID-19 pandemic. Results from the Ithaka S+R US library survey 2020. Ithaka $S+R$. https:// doi.org/10.18665/sr.314507.

Garcia Walton, L. (2021, June 17). Guest post - Designing for hybrid work: The Silverchair story. The Scholarly Kitchen [blogpost]. https://scholarlykitchen.sspnet. org/2021/06/17/guest-post-designing-for-hybrid-work-the-silverchair-story /.

Olsen, H. K. (2019). What are they doing? And where? Tracking the traffic as one of the instruments in an evidence-based redesign of a university library. LIBER Quarterly, 29(1), 1-32. https://doi.org/10.18352/lq.10276.

Wilson, K., Neylon, C., Brookes-Kenworthy, C., Hosking, R., Huang, C.-K., Montgomery, L., \& Ozaygen, A. (2019). 'Is the library open?': Correlating unaffiliated access to academic libraries with open access support. LIBER Quarterly, 29(1), 1-33. https://doi.org/10.18352/lq.10298. 